Fowler's tincture, which he has rarely found fail, especially if iron he given first. The largest dose in one day was eight drops, but he begins with a dose of one drop, aud gradually increases it. Its use is not continued after fourteen days, if no benefit results. He also uses cold water in many cases, in the shape of wet sheets.-Med. Times and Gaz., April 8, 1871.

\title{
15. A Peculiar Form of Paralysis in Children from Cerebral Softening
} occurring in Patches.-Dr. Th. Simon, of Hamburg, gives the details of three cases of this which occurred in the same family, in a boy of 4 , a girl of 3 , and a boy of 13 years of age. The course, so far as developed, was similar in the whole three cases, and a short description of the chief srmptoms may give an idea of the disease. In all the cases rickets existed, and, as regards the central nervous system, there were observed certain disturbances of the mental faculties, chiefly manifested in deficiency of memory and of speech; the boy of 4 years, for iustauce, was scarcely so far advanced as an ordinary child of 2 . There was also a considerable degree of paralysis of motion in the extremities, so that the children, after being able to walk, lost this power; yet sensibility did not seem to be affected, and the muscles contracted readily to electro-motor stimulation. In all the cases the disease dereloped itself slowly during the second year, so that in the case of the youngest child it was seen in its earlier stage. In the two elder children the affection got gradually worse, and pecnliar soporific attacks supervened, which ended fatally in the case of the girl. In this fatal case the brain and cord were examined, and very large patches of softening were found, especially on the left cerebral hemisphere, while smaller patches of a similar nature existed on the right. 'To these three fully developed cases the author adds the case of a child only 23 months old: in which numerous small patches of softening were found on both hemispheres; and he supposes that, had this patient lived, the case would have developed as the three already desclibed, while he further supposes that in the three first cases there may have been patches of softening from birth, but that they showed progressive increase from the begiuning of the second yeur onwards._Glasgow Med. Journ., May, 1871, from Virchow's Archiv, Jan. 1871.

16. Diphtheria of the Throat.-Dr. A. Cuasses, of Rostock, considers (Virchow's Archiv, Feb. 1871) that diplitleria is primarily a local disease, and that it depends on a fungus which penetrates into the epithelial cells of the mucous membrane. The result of this penetration of the epithelial cells by the fungus is a greatly increased growth of epithelium. so that layers on layers of such cells are produced, and, at the same time, white and red blood-corpuscles pass from the vessels and mix with the diseased part. 'The exudation in diphtheria he cousiders to be composed chiefly of the changed epithelial cells and blood and pus corpuscles. The fungus he has detected in the very substance of the epithelial cells, and, as it is extremely minute, he supposes that it passes from the affected membrane in to the bloodvessels, and there produces the constitutional symptoms, which are thus secondary to the primary affection of the mucous membrane. T'be presence of the fungus in the mucous membrane leads to irritation and inflammation of it, and the inflammation has the usual results; and as it is generally severe, it is commonly followed by sloughing of the mucous membrane. The author distinguishes diphtheria from croup on the one hand clinically, but on the other hand more absolutely on the ground of the presence of this fungus in diphtheria. In the early stages of diphtheria you nay have only a false inembraue on the snrface of the mucous membrane. but this has its origin in the irritation prodnced by the fungus; whereas in croup there is always a simplc inflammatiou, which is not geverally so severe as that which occurs in diphtheria, and the mucous membrane is not generally involved in the exudation. In diphtleria the coustitutioual disturbauce is greatcr than in croup, this being a natural result from the fungus passing into the blood. 'l'he alteration in the constitution of the blood effected by this fungus is considered to produce a tendency to hemorrhage, and the paralysis which is one of the common results of diphtheria is aseribed to hemorrhage into the sheaths of the nerves. 'L'o the same cause he ascribes the difficulty of hcaring and seeing 
which sometimes ensues, and supposes that when hemorrbage has occulred a slight inflammation is set up as a consequence, and that the function of the nerve is thus interfered with. A case is described where there was some loss of sight, and ophthalmoscopic examination showed the presence of a slight degree of neuro-retinitis, and this thc author ascribes to the inflammation resultiug from hemorrhage into the optic nerve near its origin. In respect to therapeutics, the author, considering the disease to be primarily a local one, and this lacal affection depending on a foreign organism, looks on the destruction of the latter as the most obvious indication. Practitioners havc come, as a rule, to use local applications to cases of diphtheria, withont any definite idea as to the disease being fundamentally local. The author has used various local applications, and here gives the result of his experience: Nitrate of silver, in solution or solid, is not advisable, as its action is too snperficial; the solution of the perchloride of iron is useful in slight cases; but be considers that the mild acids are the best agents. He has used dilnted lactic acid, which he paints on to the part; also citric acid, in the form of lemons, which were sucked in large quantities, sometimes to the number of seventy in the twenty-four hours. The acid he has found most reliable, lowever, is snlphurous acid, and this he admiuisters in the form of dry powdered sulphur (flowers of sulphur) blown on to the part, or suspended in water and used as a gargle. The grains of sulphur adhere to the mucous membrane, and by theit gradual oxidation form a continual store of sulphurous acid. I',he constitutional treatment was valied according to the cases ; in some cases leeches were used; and, where the exudation was extremely extensive, mercury was given in the form of mercurial inunction. Quinia and iron were most useful in convalescence. Latterly, he has given crystallized carbolic acid, with a view to its attacking the fungus in the blood, and he thinks he has seen great benefit delived from its use.-Glasgow Med. Journ., May, 1871.

17. Treatment of Diphtheritis.-Dr. SteIner, in the Jahrb. f. Kinderheil. (N. F. iv., 1870), after some preliminary remarks in relation to the patliology of diphtheritis, from which he comes to the conclusion that the question, whether it is to be viewed as a blood disease or one entirely local in its character, is still an unsettled one, he details the results of his experience in respect to its therapeutical management. In the course of these details, it leaks out that he is inclined to accept the doctrine of the parasitic origin of diphtheria. In cousequence, he speaks only of clllorate of potash and quinia as internal remedies, under certain circumstances, which, altogether independent of the true character of the actual malady, would call for their employment in any case of disease. His main dependence is on local remedies, applied in the form of gargling, inhalation, pencilling, or strewing. The following are briefly commented on by him :-

1. Aqua Calcis.--Lime-water was applied to the fauces in fourteen cases; of these nine had a favourable termination, and in five death took place. 'The solvent action upon the diphtheritic deposit was especially favourable; under its use, by the end of from six to eight hours, it would in great part or eutirely disappear; the lime-water in no degree, however, impedcd the recurrence of the deposit, nor had it the power to limit the disease to the fauces, and thus to guard against the danger incident to its spread into the larynx and trachea.

2. Aciulum Lacticum.-The solvent properties of the lactic acid in cases of diphtheritic deposit were first pointed out by Weber ( $C b l .1869,340)$. ITe employed it in the form of inhalation (fifteen to twenty drops to an ounce of water). The results from its use by $D_{r}$. $S$. were of the same unsatisfactory character as in the case of lime-water. Of seven cases in which it was used, three rccovered and four died. To the lactic acid must be conceded the power of dissolving the diphtheritic deposits, but, in common with all the other remedies, it exerts no power in limiting the spread of the deposit beyond the fauces.

3. Ferrum Sesquichloratum.-(Applied by means of a pencil.) By the chlorate of iron the solution and removal of the diphtheritic patches does not appear to be so speedily effected as by either of the preceding articles. Finally, however, it accomplishes the removal of the crust, thus bringing sesquichlorate in immediate contuct with the denuded mucous membrane; the latter, under its 